\title{
Reasonable Chastisement: A Critique of THE SuPREME COURT'S DECISION IN THE "SPANKING" CASE
}

\author{
SANJEEV ANAND*
}

A tremendous amount of public attention accompanied the four years it took the constitutional challenge to s. 43 of the Criminal Code 1 to make its way to the Supreme Court of Canada. In Canadian Foundation for Children, Youth and the Law v. Canada (A.G.), ${ }^{2}$ a majority of the Supreme Court ruled that the legislative provision allowing schoolteachers, parents, and persons standing in the place of parents to use reasonable force for the correction of a child is constitutionally valid. In its ruling, the Court attempted to strike a balance between those who feel that the State has no business dictating child-rearing methods to parents through its use of the criminal law power and those who feel that s. 43 sanctions violent child abuse.

Regardless of which side one is drawn toward in this divisive policy debate, the majority decision penned by McLachlin C.J. in Canadian Foundation is laudable to the extent that it provides much needed guidance as to the scope of s. 43. All of the litigants and the Court agreed that s. 43 of the Criminal Code has generated a body of jurisprudence that is "unclear and inconsistent, sending a muddled message as to what is and is not permitted"3 under the legislative provision. Chief Justice McLachlin reads a number of significant limitations into the scope of s. 43 protection by narrowly interpreting the term "correction" and the phrase "reasonable under the circumstances" contained within the legislative provision. First, she states that s. 43 provides a defence only to common assault, not to assault with a weapon, assault causing bodily harm or, presumably, any form of sexual assault. ${ }^{4}$ Section 43 can only be invoked "in cases of non-consensual application of force that results neither in harm nor in the prospect of bodily harm." According to McLachlin C.J.'s judgment, "[g]enerally, s. 43 exempts from criminal sanction only minor corrective force of a transitory and trifling nature." This legislation provides no protection where force is used against children under the age of two, against teenagers, or against children of any age who suffer from a disability that renders them incapable of learning from the correction. " Degrading, inhuman or harmful conduct is not protected ... [nor is discipline] by the use of objects or blows or slaps to the head." Although "teachers may reasonably apply force to remove a child from a classroom or secure compliance with instructions," teachers are prohibited from inflicting corporal

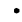

Associate Professor, Faculty of Law, University of Alberta. The author thanks Marla Teeling for her tireless research assistance, Nicholette Anand for her invaluable editing, and Priya Anand for her patience during the writing process.

R.S.C. 1985, c. C-46 [Criminal Code].

Canadian Foundation for Children, Youth and the Lavv v. Canada (A.G.), (2004), 234 D.L.R. (4th) 257, [2004] S.C.J. No. 6 (QL) [Canadian Foundation cited to QL].

Ibid. at para. 39.

Ibid. at para. 30. For a thoughtful analysis of the jurisprudence that held that the s. 43 defence is applicable to charges of sexual assault, see Mark Carter, "The Corrective Force Defence (section 43) and Sexual Assault" (2001) 6 Can. Crim. L. Rev. 35.

Canadian Foundation, supra note 2 at para. 30.

Ibid. at para. 40.

Ibid. at para. 25.

Ibid. at para. 40.

Ibid. 
punishment on pupils. ${ }^{10}$ Because the conduct protected by s. 43 must be corrective, applications of force stemming from the caregiver's frustration, loss of temper, or abusive personality are beyond the ambit of the legislation. " Chief Justice McLachlin also warns that it is an error "for law enforcement officers or judges to apply their own subjective views of what is 'reasonable under the circumstances"' because this aspect of s. 43 must be addressed on an objective basis. ${ }^{12}$ Finally, McLachlin C.J. states that, in assessing what constitutes reasonable force for the purposes of a s. 43 analysis, the gravity of the child's actions should not be considered. The reasonable force used in response to the child's actions should have a corrective as opposed to a punitive focus. ${ }^{13}$ While it is true that the dissenting judges take issue with how McLachlin C.J. formulates these restrictions on the scope of s. $43,{ }^{14}$ they do not dispute that her judgment brings much needed clarity to a confusing area of the law.

Nevertheless, there are problematic aspects to McLachlin C.J.'s ruling. Although her conclusion that s. 43 does not violate s. 7 of the Charter of Rights and Freedoms ${ }^{15}$ is reasonable, her analysis of the s. 7 claim is incomplete, lacks cogency, and is difficult to reconcile with past cases. Chief Justice McLachlin's equality rights analysis is even more fraught with difficulties. Indeed, when one takes into account previous dicta of the Supreme Court pertaining to s. 43 and important animating principles of criminal law ignored by the majority, the propriety of McLachlin C.J.'s conclusion that s. 43 does not violate s. 15 becomes doubtful. In addition, the Court adopts a novel and somewhat dubious perspective with which to view equality rights claims from children. Finally, McLachlin C.J. misses an historic opportunity to resolve a debate as enduring as the debate around the proper scope of s. 43: whether or not a defence of de minimis exists in Canadian criminal law.

\section{The Court's Determination THAT SECTION 43 OF THE CRIMINAL CODE DOES NOT INFRINGE SECTION 7 OF THE CHARTER}

The Crown conceded that s. 43 adversely affects children's security of the person. As a result, the Court properly focuses on the issue of whether this breach was in accordance with the principles of fundamental justice.

Ibid.

Ibid.

Ibid. at para. 35 .

In particular, the dissenting judges question the propriety of engaging in extensive reading down of a statutory provision prior to subjecting the provision to constitutional scrutiny, especially when some of the narrow interpretations adopted by the Court are not readily gleaned from the wording of the statutory provision or the jurisprudence decided under it. Although Arbour J. suggests that engaging in such action "is to hide the constitutional imperative" (ibid. at para. 139) and Binnie J. holds that extensive reading down should only be engaged in as a constitutional remedy (ibid. at para. 103), the Supreme Court has, on a number of occasions, engaged in extensive and sometimes novel acts of reading down statutory provisions prior to subjecting the provisions to constitutional analyses (see, for example, R. v. Sharpe, [2001] I S.C.R. 45; R. v. Keegstra, [1990] 3 S.C.R. 697; R. v. Butler, [1992] I S.C.R. 452; and the dissenting judgment of Cory and lacobucci JJ. in R. v. Zundel, [1992] 2 S.C.R. 731). Nevertheless, Arbour J. makes a compelling point when she states that " $[i] \mathrm{t}$ is wholly unpersuasive for this Court to declare today what the law is de novo and to assert that this now frames the legal debate" (Canadian Foundation, ibid. at para. 181).

is Part I of the Constitution Act, 1982, being Schedule B to the Canada Act 1982, (U.K.), 1982, c. 11 [Charter]. 
With a few exceptions, the Chief Justice's analysis of the principles of fundamental justice focuses on ielatively established principles articulated in previous cases.

Consequently, the majority does not address an interesting argument that has its origins in s. 12 of the Charter and the Supreme Court's first rendered judgment pertaining to s. 7, Re B.C. Motor Vehicle Act. ${ }^{16}$ Rodriguez v. British Columbia (A.G.) $)^{17}$ makes clear that, to engage s. 12 of the Charter, the section that specifically protects against cruel and unusual treatment or punishment, there must be a direct State nexus to the punishment or treatment imposed. In the context of parents' use of force against children authorized by s. 43, the direct nexus to the punishment or treatment imposed is not to the State, but to the parents. Thus, s. 12 of the Charter is not infringed by s. 43 . It is also apparent that if the requirement of direct State nexus to the punishment or treatment imposed was not present, a s. $12 \mathrm{claim}$ against s. 43 would likely succeed because in $R$. v. Smith, corporal punishment was held to always constitute cruel and unusual punishment ${ }^{18}$ and because the majority in Canadian Foundation interprets s. 43 as authorizing corporal punishment of children by their parents.

In the Motor Vehicle Act Reference, the Supreme Court expressed a residuary theory of s. 7 under which ss. 8 to 14 of the Charter are simply illustrations of s. $7 .{ }^{19}$ In later cases, the Court held that even when a legislative provision does not infringe ss. $8-14$, because of the relatively precise language used to articulate these sections of the Charter, the residual elements of these rights may inform a s. 7 analysis. ${ }^{20}$ It is unclear whether there is a residual element of cruel and unusual punishment contained within the principles of fundamental justice and, if there is, it is also unclear whether there is enough of this element to call into question the constitutional validity of s. 43 . It is evident that an exploration of this issue by the Supreme Court would have had benefits that extend beyond the area of corrective force against children. The majority missed an opportunity to shed some light on the relationship between s. 7 and the rest of the legal rights provisions in the Charter.

One of the most surprising pronouncements to emanate from Canadian Foundation is that it is not a principle of fundamental justice that laws affecting children must be in their best interests. ${ }^{21}$ On a number of occasions, various judges of the Supreme Court have suggested that it is one of the principles of fundamental justice that decisions about children must be made according to the best interests of the child. Most notably, in New Brunswick (Minister

[1985] 2 S.C.R. 486 [Motor Vehicle Act Reference].

Rodriguez v. British Columbia (A.G.), [1993] 3 S.C.R. 519 [Rodriguez].

[1987] I S.C.R. 1045 at 1074 [Smith].

Motor Vehicle Act Reference, supra note 16 at 502-503.

For example, in Thomson Newspapers v. Canada, [1990] I S.C.R. 425, a corporation and its officers objected to a demand made under anti-competition legislation for oral examination of the officers. Although the purpose of the demand was to inquire into the possible commission of an offence by the corporation, neither of the two express Charter guarantees against self-incrimination was applicable. Section 11(c), which provides that a person charged with an offence is not a compellable witness against himself, did not apply because no one had been charged with an offence. Section 13, which provides that self-incriminatory evidence given in one proceeding cannot be used against the witness in another proceeding, was also not applicable because this inquiry was the first proceeding. The Court ruled that ss. 11 (c) and 13 of the Charter were not the only provisions that incorporated the right against self-incrimination and that the principles of fundamental justice in $\mathrm{s} .7$ contained some residual elements of this right (ibid.).

Canadian Foundation, supra note 2 at paras. 7-12. 
of Health) v. G.(J.), the Court held "that state removal of a child from parental custody pursuant to the State's parens patriae jurisdiction constitutes a serious interference with the psychological integrity of the parent" ${ }^{\prime 22}$ and the child and it is this effect that infringes the security of the person of both parent and child within the meaning of s. 7 of the Charter. ${ }^{23}$ The Court also stated: "the principles of fundamental justice [within the meaning of s. 7] in child protection proceedings are both substantive and procedural. The state may only relieve a parent of custody when it is necessary to protect the best interests of the child, provided that there is a fair procedure for making this determination." ${ }^{24}$ Dissenting in Winnipeg Child and Family Services v. K.L.W., ${ }^{25}$ Arbour J. was even more explicit in recognizing the best interests of the child as a principle of fundamental justice: "I would suggest, therefore, that to satisfy the substantive content of the principles of fundamental justice in the child protection context, the apprehension of a child by a state agency requires an evaluation of the best interests of the child." Thus, it can be asserted that the Supreme Court in Canadian Foundation is not merely failing to recognize that the best interests of the child constitutes a principle of fundamental justice. In fact, the Supreme Court is repudiating that this recognition was previously made at all.

Chief Justice McLachlin makes abundantly clear her basis for concluding that the best interests of the child is not a principle of fundamental justice. Such an expansive principle of fundamental justice would mean that $\mathrm{s}$. 7 would be found to be infringed by a myriad of State actions. She postulates that recognizing this legal principle as a principle of fundamental justice would mean that the State would be constitutionally barred from imposing sentences of incarceration upon an offender where it is not in his or her child's best interests that the offender go to prison. ${ }^{26}$

Nevertheless, McLachlin C.J. could have recognized a less expansive, more qualified form of the best interests of the child principle. A qualified form of this principle would have allowed the Court to reconcile cases such as G.(J.) with Canadian Foundation without creating unworkable constitutional impediments. ${ }^{27}$ Indeed, in Quebec (Ministre de la Justice) c. Canada (Ministre de la Justice), the Quebec Court of Appeal concluded that it is a principle of fundamental justice that the youth justice system must consider the best interests of the child. ${ }^{28}$

In Canadian Foundation, McLachlin C.J. recounts that to be considered a principle of fundamental justice, the principle must be a legal principle, it must be "vital or fundamental

[1999] 3 S.C.R. 46 at para. 61 [G.(J.)].

Ibid. at paras. 61 and 76.

Ibid. at para. 70 .

[2000] 2 S.C.R. 519 at para. 9 [K.L.W.].

Canadian Foundation, supra note 2 at para. 10.

Professor Nicholas Bala suggests that Canadian Foundation should not be read as overruling the Court's previous child welfare jurisprudence that recognized the best interests of the child as a principle of fundamental justice. Instead, he argues that Canadian Foundation should be given a restrictive reading so that it simply stands for the proposition that the best interests of the child is not a principle of fundamental justice in the criminal law context (see Nicholas Bala, "The Charter of Rights \& Child Welfare Law" (paper presented as part of the Law Society of Upper Canada program on Conduct of $A$ Child Protection File, March 2004) [unpublished]).

(2003), 10 C.R. (6th) 281 at paras. 215 and 231 [Youth Justice Reference]. 
to our societal notion of justice," ${ }^{29}$ and it must be capable of being identified with some precision and provide a justiciable standard. ${ }^{30}$ Chief Justice McLachlin acknowledges that the best interests of the child is a legal principle. However, she holds that this principle is not vital or fundamental to our societal notion of justice. Chief Justice McLachlin maintains that in order to fulfill this criterion, the principle cannot be subordinated to other concerns. ${ }^{31}$ This statement has profound implications. The first implication is that principles of fundamental justice must be absolute, not qualified, principles. If this is true, the Quebec Court of Appeal's judgment in Youth Justice Reference is suspect. The second implication is that there can be no role for s. 1 justifications of s. 7 breaches. And if this is correct, the Supreme Court's traditional methodology, whereby it has always conducted a s. 1 analysis upon finding that a law has breached s. 7 , serves no purpose..$^{32}$

Chief Justice McLachlin further buttresses her ruling that the best interests of the child is not a principle of fundamental justice by concluding that the best interests of the child falls short of providing a justiciable standard because "reasonable people may well disagree about the result that its application will yield." 33 This definition of what constitutes a justiciable standard sets the bar too high. On the basis of McLachlin C.J.'s definition, vagueness - a principle of fundamental justice long recognized by the Supreme Court and one relied upon by Arbour J. in her dissenting judgment in Canadian Foundation to strike down s. 43 should no longer be considered a principle of fundamental justice. Since McLachlin C.J. and Arbour J. come to diametrically-opposed conclusions regarding whether s. 43 is unconstitutionally vague, does this mean that one of these Justices is not a "reasonable person"?

Even if the Court recognized that it is a principle of fundamental justice that the best interests of the child be considered in the adult justice system, it does not necessarily follow that s. 43 would be held to infringe s. 7. Indeed, given the characterization of s. 43 as being beneficial to children, espoused by McLachlin C.J. during her equality rights analysis, she likely would have held that s. 43 did not violate s.7's qualified best interests of the child principle of fundamental justice.

\section{The Court's Determination that SECTION 43 OF THE CRIMINAL CODE Does Not INFRINGE SECTION 15 OF THE CHARTER}

The majority is able to conclude that $\mathrm{s} .43$ does not infringe the equality rights provision of the Charter largely because McLachlin C.J. fails to acknowledge the significance of the Court's previous s. 43 jurisprudence. Ogg-Moss v. $R^{34}$ is the only case prior to Canadian

Supra note 2 at para. 7, quoting the Court's decision in Rodriguez, supra note 17 at 590.

Ibid. at para. 8.

lbid. at para. 10.

This may, in fact, be true, although the Supreme Court has never explicitly acknowledged it. For example, although the Court in R. v. Morgentaler, [1988] I S.C.R. 30 conducted a s. I analysis after finding that the therapeutic abortion provisions of the Criminal Code infringed s. 7, the s. 1 analysis was very reminiscent of the analysis completed under s. 7. Furthermore, Peter Hogg notes that the Supreme Court has never upheld a particular breach of $s .7$ as being justified under s. 1 (Constitutional Law of Canada, loose-leaf (Toronto: Carswell, 2003) at 44.3.)

Canadian Foundation, supra note 2 at para. 11.

[1984] 2 S.C.R. 173. 
Foundation in which the Supreme Court interpreted s. 43. Although not within the context of a Charter challenge, the Court concluded in that ruling that s. 43 attenuates children's rights to dignity and transforms them into second-class citizens. ${ }^{35}$ This dicta assumes heightened importance when one considers that in Law v. Canada, the Supreme Court held that a distinction based on a listed or analogous ground would not amount to discrimination under s. 15 unless the distinction was also a violation of essential human dignity. ${ }^{36}$

Even without the Court's dicta in Ogg-Moss, it seems an inescapable conclusion that s. 43 infringes s. 15 of the Charter. By virtue of this legislative provision, children are now the only class of persons in Canada - including convicted criminals - who can be corporally punished with criminal impunity. ${ }^{37}$

Nonetheless, the majority in Canadian Foundation is able to conclude that s. 43 does not violate $s .15$ by maintaining that this legislative provision promotes the healthy development of children while simultaneously protecting them from harm. In $L a w$, the Supreme Court stated that laws are not to be regarded as discriminatory when they "are sensitive to the needs, capacities and merits of different individuals, taking into account the context underlying their differences." ${ }^{38}$ In Canadian Foundation McLachlin C.J. does not suggest that children benefit from or need corporal punishment. She maintains that children need a stable and secure family and school setting and that without s. 43 , the criminal law may disrupt children's families and educational environments by allowing for assault charges to be laid against parents and teachers even when they use only minimal force of transient or trivial impact on children. ${ }^{39}$

It is clear that McLachlin C.J.'s s. 15 analysis of s. 43 is premised upon the need to shield from criminal liability the parent that uses mild spanking on his or her children. The majority assumes that if s. 43 is struck down, parents will continue to use corporal punishment and risk criminal liability rather than alter their child-rearing practices. Consequently, the majority's analysis completely ignores the educative effect of criminal law. As stated by John Turner, then the Federal Minister of Justice:

[The law] tends within the conduct that is prescribed to articulate the values by which we Canadians seek to live. The criminal law is not merely a sanction or control process. It is reflective and declaratory of the moral sense of a community and the total integrity of a community. It seeks not merely to proscribe but to educate. It seeks to set forth a threshold of tolerance and standards of minimum order and decency. ${ }^{40}$

Ibid. at 187.

Law v. Canada (Minister of Employment and Immigration), [1999] 1 S.C.R. 497 at para. 88 [Lawi]. Both Binnie and Deschamps JJ. in their dissenting judgments rely upon the passage from Ogg-Moss, supra note 34 to bolster their conclusion that s. 43 infringes s. 15 (see Canadian Foundation, supra note 2 at paras. 109 and 231).

Greg M. Dickinson, "Spanking Law Gets Constitutional Nod from Ontario Court of Appeal" (2002) 12 Educ. \& L.J. 257 at 267.

Law, supra note 36 at para. 53 .

Canadian Foundation, supra note 2 at para. 59.

House of Commons Debates (6 April 1970) at 5557. 
In fact, there is evidence that many countries that have banned the corporal punishment of children, such as Sweden, have experienced large attitudinal shifts among their populace towards the use of corporal punishment. ${ }^{41}$

The last troublesome aspect of the majority's s. 15 analysis concerns the perspective that it uses to assess whether human dignity has been infringed. According to Law, the relevant point of view is that of the reasonable person, in circumstances similar to those of the claimant, who takes into account the contextual factors relevant to the claim. ${ }^{42}$ Thus, the Court in Canadian Foundation should have examined the question of whether s. 43 infringes the human dignity of a child from the perspective of the reasonable child. Nevertheless, the majority assesses this issue from the perspective of the reasonable person acting on behalf of the child. ${ }^{43}$ This perspective risks ignoring significant concerns that children may possess simply because those concerns are not deemed reasonable by a mature adult. Moreover, adopting this perspective opens the Court to criticisms that its approach to s. 15 claims brought by children is paternalistic.

It is difficult to understand why the majority of the Court in Canadian Foundation decided to deviate from the approach to assessing s. 15 claims articulated in Law. At this point in time it is also difficult to determine whether Canadian Foundation marks a change in how the Court will assess all equality rights claims or whether this new methodology will be restricted to equality claims made by children. Most adults do remember what it was like to be a child and, therefore, they could apply a reasonable child standard in assessing a s. 15 claim brought by a young person. It would be far more difficult for most judges to appreciate the perspective of the reasonable physically- or mentally-disabled claimant or the reasonable claimant of colour.

\section{The Court's Reluctance to Definitively Recognize THE DEFENCE OF DE MINIMIS}

Even those who wished to see s. 43 struck down acknowledge that there will be times when force must be used to restrain children. The majority accepts that the common law defence of necessity is applicable, "but only in situations where corrective force is not in issue, like saving a child from imminent danger." ${ }^{" 44}$ Clearly McLachlin C.J. does not believe that a parent can use the defence of necessity to enforce a "time-out."

It seems that such a minimal use of force might come within a defence of de minimis, which excuses an offender for committing a technical, but trivial, infringement of the law.

4 Canada, Department of Justice, Literature Review of Issues Related to the Use of Corrective Force Against Children (Working Document WD1993-6e) by Nanci M. Burns (Ottawa: Department of Justice, 1993) at 17 and 42; and Terese Henning, "One Little Smack - Will You Be In The Slammer?" (2003) 27 Crim L.J. 293 at 301 . It should be noted that those nations that coupled the banning of corporal punishment of children with extensive public education campaigns concerning optimal parenting practices achieved the best long-term changes in attitudes and beliefs.

42 Law, supra note 36 at paras. 60-61.

43 Canadian Foundation, supra note 2 at para. 53.

t4 Ibid. at para. 44. 
However, the existence of this defence is a matter of some dispute and prior to the release of Canadian Foundation, the Supreme Court of Canada had not taken a firm position on it. ${ }^{45}$

It is lamentable that McLachlin C.J. did not definitively address the existence of this defence in Canadian Foundation because it is unlikely that the Supreme Court will have another opportunity to address this issue in the near future. There will not be an opportunity because an appellate review must be initiated by one of the parties to litigation. If the defence of de minimis is not recognized by a trial court and the accused is found guilty of the offence, even though it was a trivial infringement of the criminal law, it is likely that the offender will receive a discharge. Consequently, he or she likely will not be motivated to appeal his or her finding of guilt. Furthermore, if the defence is recognized by the trial court and the accused is acquitted, the Crown likely will not opt to appeal the matter because the trivial nature of the offence will not be deemed sufficient to warrant the expenditure of State resources necessary to launch and hear an appeal.

Indeed, it would have been salutary if McLachlin C.J. had joined Binnie and Arbour JJ. in accepting the existence of the de minimis defence. Such a defence would constitute a useful vehicle of restraint upon the criminal law, one that is sorely needed in light of the Supreme Court's recent rejection of a harm principle as a principle of fundamental justice. ${ }^{46}$

Alas, the most that can be said for the majority's judgment is that it does not expressly recognize the defence of de minimis, but it also does not explicitly refuse to recognize it.

\section{CONCLuSION}

At first glance, the majority's decision not to explicitly recognize the defence of de minimis is puzzling. However, it may be naive to believe that McLachlin C.J.'s failure to address this issue was a mere oversight. If a common law defence of de minimis was available, it would be more difficult to constitutionally justify s. 43 either internally within s. 15 or externally under s. 1. The Court may have been keenly aware that if it struck down s. 43, it would risk incurring the wrath of that segment of the public which desires a protected sphere of parental autonomy. Thus, by retaining s. 43 , the Court may be perceived as solicitous of parents' rights. Yet, by essentially reading down the s. 43 defence so that it is a de facto statutory equivalent to a de minimis defence, albeit a de minimis defence that is limited to the child correction area, the majority's judgment also has significant appeal to that portion of the populace which is concerned that the State adequately protect children from violence.

Academics often remark that the Supreme Court is sensitive to public opinion even though it claims not to be. ${ }^{47}$ The Court's ruling in the "spanking" case could be viewed as strong circumstantial evidence supporting the position of these court watchers.

45 For information on the history of the principle that the law is not concerned with trivialities and its uneven recognition and application in Canadian courts, see Don Stuart, Canadian Criminal Law: A Treatise, 4th ed. (Toronto: Carswell, 2001) at 594-99.

See R. v. Malmo-Levine (2003) 16 C.R. (6th) 1 .

See e.g. the comments of Professor Choudhry, quoted in Kirk Makin, "Critics of Supreme Court off base, study says; Analysis by academic debunks charges that judicial activism is on the increase" The Globe and Mail (2 February 2004) A4. 